\title{
Essential oils as growth-promoting additives on performance, nutrient digestibility, cecal microbes, and serum metabolites of broiler chickens: a meta-analysis
}

\author{
Agung Irawan $^{1,2, *}$, Cecep Hidayat ${ }^{2,3}$, Anuraga Jayanegara ${ }^{2,4}$, and Adi Ratriyanto ${ }^{5}$
}

\footnotetext{
* Corresponding Author: Agung Irawan Tel: +62-821-4537-6027.

E-mail: a.irawan@staff.uns.ac.id

${ }^{1}$ Vocational Program in Animal Husbandry, Vocational School, Universitas Sebelas Maret, Surakarta 57126, Indonesia

2 Animal Feed and Nutrition Modelling Research Group (AFENUE), Department of Nutrition and Feed Technology, Faculty of Animal Science, IPB University, Bogor 16680, Indonesia

${ }^{3}$ Indonesian Research Institute for Animal

Production, Ciawi Bogor 16720, Indonesia

${ }^{4}$ Department of Nutrition and Feed

Technology, Faculty of Animal Science, IPB

University, Bogor 16680, Indonesia

${ }^{5}$ Department of Animal Science, Faculty

of Agriculture, Universitas Sebelas Maret,

Surakarta 57126, Indonesia

ORCID

Agung Irawan

https://orcid.org/0000-0003-1179-0469

Cecep Hidayat

https://orcid.org/0000-0002-8856-661X Anuraga Jayanegara

https://orcid.org/0000-0001-7529-9770

Adi Ratriyanto

https://orcid.org/0000-0001-9656-9135
}

Submitted Sept 22, 2020; Revised Nov 7, 2020 Accepted Dec 11, 2020
Objective: The purpose of this meta-analysis was to evaluate the effect of dietary essential oils (EOs) on productive performance, nutrient digestibility, and serum metabolite profiles of broiler chickens and to compare their effectiveness as growth-promoting additives against antibiotics.

Methods: Peer-reviewed articles were retrieved from Web of Science, Science Direct, PubMed, and Google scholar and selected based on pre-determined criteria. A total of 41 articles containing 55 experiments with 163 treatment units were eligible for analyses. Data were subjected to a meta-analysis based on mixed model methodology considering the doses of EOs as fixed effects and the different studies as random effects.

Results: Results showed a linear increase $(\mathrm{p}<0.001)$ on body weight gain $(\mathrm{BWG})$ where Antibiotics (FCR) and average daily feed intake decreased $(\mathrm{p}<0.001)$ linearly with an increasing dose of EOs. Positive effects were observed on the increased $(\mathrm{p}<0.01)$ digestibility of dry matter, crude protein, ether extract, and cecal Lactobacillus while Escherichia coli (E. coli) population in the cecum decreased $(\mathrm{p}<0.001)$ linearly. There was a quadratic effect on the weight of gizzard $(\mathrm{p}<0.01)$, spleen $(\mathrm{p}<0.05)$, bursa of fabricius $(\mathrm{p}<0.001)$, and liver $(\mathrm{p}<$ $0.10)$ while carcass, abdominal fat, and pancreas increased $(p<0.01)$ linearly. The dose of EOs linearly increased high density lipoprotein, glucose, protein, and globulin concentrations $(\mathrm{p}<0.01)$. In comparison to control and antibiotics, all type of EOs significantly reduced $(p<0.001)$ FCR and tended to increase $(p<0.1)$ BWG and final body weight. Cinnamaldehydecompound was the only EOs type showing a tendency to increase $(\mathrm{p}<0.1)$ carcass weight, albumin, and protein of serum metabolites while this EOs together with EOs-Blend 1 decreased $(\mathrm{p}<0.01)$ E. coli population. Low density lipoprotein concentration decreased $(\mathrm{p}<0.05)$ with antibiotics and carvacrol-based compound when compared to the control group.

Conclusion: This evidence confirms that EOs are suitable to be used as growth promoters and their economical benefit appears to be promising.

Keywords: Antibiotics; Broiler; Essential Oils; Growth Promoter; Meta-analysis; Production Performance

\section{INTRODUCTION}

Global pressure to replace the use of antibiotics as growth promoters (AGPs) with safe feed additives in the broiler industry has led researchers to conduct a massive exploration in utilizing natural substance-based additives. It is primarily due to the AGPs restricted use by the European Union since 2006 concerning antimicrobial resistance, human health, and sustainability [1]. Essential oils (EOs), volatile properties derived from plant materials by mainly steam distillation method, are among promising growth enhancers in broiler chickens that received a growing interest among scholars and industrial stakeholders. 
EOs are formed by dozens of complex mixture components [2] that can be classified into a group of terpenoids (menthol, linalool, geraniol, borneol, $\alpha$-terpineol) and a group of low molecular weight aliphatic hydrocarbons (thymol, carvacrol, eugenol, cinnamaldehyde). The advantageous effects of EOs are associated with their role on many metabolic pathways, including on lipid metabolism, stimulate digestive enzyme secretion and activity, act as antimicrobial, and enhance gut integrity of chickens $[3,4]$ leading to improve broiler performance in general.

However, inconsistent results among past and present studies are identified to be conflicting. For instance, there were positive effects of EOs on broiler performance as indicated with improving body weight gain (BWG) $[5,6]$, feed conversion ratio (FCR) [7], enzyme secretion [8], and nutrients digestibility [9-11]. In addition, previous report also revealed that EOs supplementation effectively replaced the use of AGP [12]. On the other hand, there were contrary reports where several authors suggested no effect of dietary EOs on broiler productive performance $[13,14]$ or even had lower weight gain compared to those not receiving AGP or EOs [15]. Major explanations from these contradictory findings have been attributed to the different of EOs active components used in the individual study, their natural origin such as plant source, plant part, geographical condition, and also environmental and physiological factors of the animal used $[3,11]$. Indeed, the mode of action from specific EOs molecules is limited to elucidate different results from a number of studies. The magnitude of the biological effect of EOs varies depending on the complex chemical structure of EOs.

Comprehensive reviews describing the main effect and mode of action of EOs on poultry have been provided [3,4, 17]. However, to our knowledge, the effects of EOs on broiler chickens have not been summarized quantitatively to date. Data from available empirical studies can be integrated and quantified using a robust statistical method, i.e., the metaanalysis because the method considers heterogeneity among individual studies which increases the power to calculate the treatment effect $[18,19]$. Therefore, this study aimed to investigate the efficacy of the application of EOs as alternative growth-promoting additives in the diet on the productive performance of broiler chickens.

\section{MATERIALS AND METHODS}

\section{Database development and inclusion criteria}

A database was developed based on scientific publications available online at several search engines such as Web of Science, Science Direct, and PubMed. Keywords used in this study were "broiler performance" and "essential oil" or "phytogenic". To specify the result of the browsing process, we used several filters available on the website such as type of article, range of year of publication, and journal name. Journal name filter was used to exclude irrelevant journals that appeared during searching the database such as journal related to aquaculture and food science. All relevant titles of publication from the respective websites were further imported into the reference manager for selection purposes.

In total, 124 published articles were identified to match the purpose of this study based on the title of the article. These data were further assessed with qualification criteria developed according to the guidelines of Preferred Reporting Items for Systematic Reviews and Meta-Analyses (PRISMA) to ensure the quality of the meta-analysis [20]. Assessment criteria were, i) research articles published between 2006 to 2019 from a peer-reviewed journal, ii) in vivo trials containing control group and EOs treatment group, iii) articles not containing antibiotics used as a growth promoter in the control or EOs group except for the AGP used as a positive control, iv) articles reporting experimental periods, and at least performance parameters of final body weight (BW) or weight gain and feed intake or FCR, and v) articles reporting the EOs sources or major type of EOs and supplementation dose.

In addition, studies conducted before 2006 were excluded because it was the period in which the use of AGP in feed was permitted thereby difficult to measure the only effect of EOs inclusion. The EOs may also have been supplemented through feed or drinking water. In this study, only those administered in feed were integrated into the database. This meta-analysis also ruled out the bacterial challenged studies because they were not the focus of the current study. Because other substances such as organic acids can potentially interfere with the effect of EOs, studies that used organic acid products containing EOs compounds were excluded. Additionally, EOs treatments with $\geq 1,000 \mathrm{mg} / \mathrm{kg}$ were disregarded because the number of these categories was small ( $\mathrm{n}$ total of this category $=9$ observations). Finally, 41 studies comprising 55 experiments and 163 treatment units were eligible and therefore used for the analysis. Details for the selection process of database development are provided in Figure 1 while the summary of the studies is presented in Table 1.

\section{Data extraction}

The information about the journal, authors, year of study, broiler used (including strain and sex), diet type, length of study, treatment, type and composition of EOs, doses of EOs, nutritional specification of the diet, and the mean value of each parameter contained in the study was recorded in a spreadsheet. The parameters included in the database were productive performance (BW, BWG, feed intake (FI), FCR, average daily feed intake $[\mathrm{ADFI}]$ ), nutrients digestibility (dry matter $[\mathrm{DM}]$, organic matter $[\mathrm{OM}]$, crude protein $[\mathrm{CP}]$, crude 


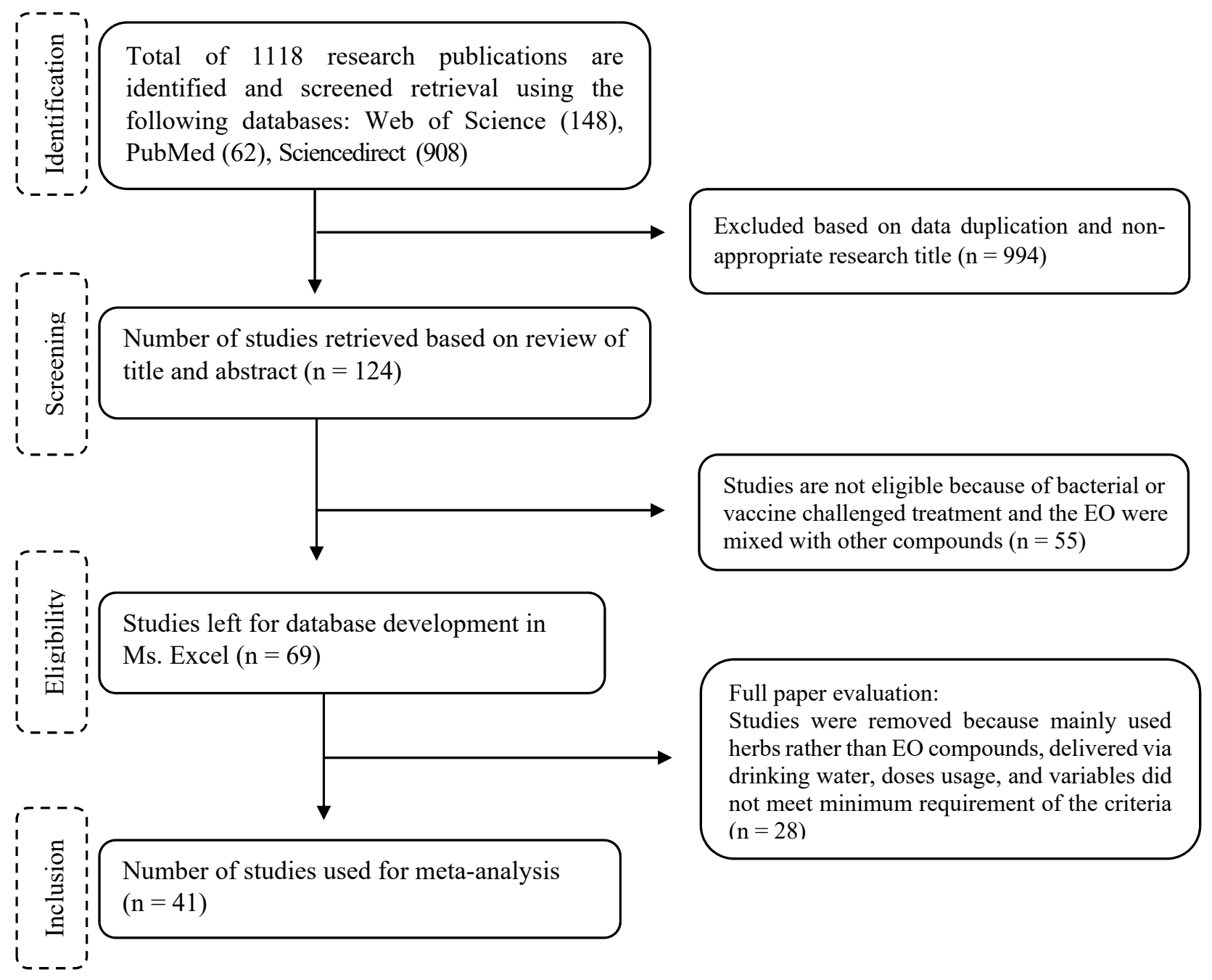

Figure 1. Flow charts of publications utilized for the meta-analysis.

fiber [CF], ether extract [EE]), organ weight, intestinal morphology and cecal microbes, and serum metabolite parameters. Summary of nutrient specification of diets is shown in Table 2 and the descriptive statistics of the response variables is presented in Table 3. To obtain the exact values from graphical data, the relevant figures from the papers were subjected to an online extraction tool of WebPlotDigitizer (https:// apps.automeris.io/wpd/). All observed data were transformed into the same measurement units for analysis. The sample size for each parameter was calculated. Several parameters such as mortality, OM and CF digestibility, immunoglobulin $\mathrm{M}$, immunoglobulin $\mathrm{Y}$, and several blood metabolites were not eligible to be included because they had relatively small sample sizes $(\mathrm{n}<10)$.

\section{Description of the database}

This study included 16,221 broiler chickens averaging 395 $( \pm 87.7)$ birds per study. The strain used was dominated by Ross 308 which accounted for $73 \%$ while Cobb 500 was $17 \%$ and the other 10\% were Arbor Across and Hubbard. All studies described broiler chickens' sex used (of which $68 \%$ were male, $17 \%$ mixed, $10 \%$ unsex, and the rest was female). As much as $70.7 \%$ of all studies used maize - soybean meal based diet. The average duration of the evaluated study was $36 \mathrm{~d}$, the maximum length was $46 \mathrm{~d}$, and the minimum was $9 \mathrm{~d}$. In $90.2 \%$ of the experiments, birds received starter diet, while grower and finisher diets were offered to $54.6 \%$ and $58.9 \%$ of the experiments, respectively. Nutrient specifications of all experiments were summarized for metabolizable energy (ME, kcal/kg), CP (\%), and total lysine (\%). As given in Table 2, the average of ME, CP, EE, and lysine of the diet provided to the starter, grower, and finisher phases were appropriate with the nutrient requirement of broiler chickens according to NRC [21].

The EOs are a complex mixture of a variety of bioactive compounds. In application, it is largely administered with one to three major components and some trace bioactive compounds, thus the term of EOs is used onward regardless 
Table 1. Description of the studies included in the database

\begin{tabular}{|c|c|c|c|c|}
\hline Authors & Birds (n) & Period (d) & Essential oils & Dose $(\mathrm{mg} / \mathrm{kg})$ \\
\hline Loh et al [56] & 96 & $0-21$ & Blend (thy, ane) & $0-150$ \\
\hline Ciftci et al [57] & 240 & $5-42$ & Cinnamon EOs & $0-500$ \\
\hline Isabel and Santos [58] & 660 & $0-46$ & Blend (clove \& cinnamon EOs) & $0-100$ \\
\hline Malayoğlu et al [30] & 450 & $0-21$ & oregano EOs & $0-500$ \\
\hline Tiihonen et al [51] & 720 & $0-42$ & Blend (thy, cin) & $0-20$ \\
\hline Amad et al [9] & 528 & $0-42$ & Blend (thy, ane) & $0-750$ \\
\hline Amerah et al [59] & 192 & $0-35$ & Blend (cin, thy) & $0-100$ \\
\hline Alp et al [60] & 1200 & $0-42$ & Oregano EOs & $0-300$ \\
\hline Bravo et al [61] & 240 & $0-21$ & Blend (car, cin) & $0-100$ \\
\hline Bozkurt et al [62] & 1248 & $0-42$ & Blend (car, 1,8-cin, cam, thy) & $0-48$ \\
\hline Engberg et al [63] & 640 & $0-35$ & Artemisia annua oil EOs & $0-500$ \\
\hline Mueller et al [64] & 240 & $0-35$ & Blend (turmeric, oregano, thyme, rosemary EOs) & $0-150$ \\
\hline Hashemipour et al [27] & 240 & $0-42$ & Blend (thy, car) & $0-200$ \\
\hline Sarica and Corduk [65] & 135 & $0-21$ & Oregano EOs, pepper EOs & $0-250$ \\
\hline Betancourt et al [66] & 750 & $0-42$ & Oregano EOs & $0-200$ \\
\hline Habibi et al [67] & 168 & $0-49$ & Ginger root EOs (zin, $\beta$-ses, sab, ar-cur, $\beta$-bis) & $0-150$ \\
\hline Humer et al [68] & 432 & $0-35$ & Blend (thy, ane) & $0-150$ \\
\hline Khattak et al [5] & 960 & $0-42$ & $\begin{array}{l}\text { Blend (EOs from basil, caraway, laurel, lemon, } \\
\text { oregano, sage, tea, and thyme) }\end{array}$ & $0-60$ \\
\hline Ghazi et al [69] & 120 & $0-42$ & Oregano EOs & $0-250$ \\
\hline Pirgozliev et al [70] & 310 & $0-21$ & Blend (cin, car) & $0-100$ \\
\hline Aristimunha et al [12] & 930 & $0-42$ & Blend (thy, eug, pip) & $0-300$ \\
\hline Hafeez et al [71] & 600 & $0-42$ & Blend (men, ane) & $0-100$ \\
\hline Basmacioğlu-Malayoğlu et al [10] & 240 & $0-42$ & Blend (car, cum, eug) & $0-300$ \\
\hline Kim et al [6] & 840 & $0-35$ & Blend (thy, ane) & $0-150$ \\
\hline Ding et al [72] & 192 & $0-42$ & Star anise EOs (ane) & $0-200$ \\
\hline Masouri et al [33] & 288 & $0-42$ & Khuzistanica EOs (car) & $0-500$ \\
\hline Mohiti-Asli and Ghanaatparast-Rashti [73] & 200 & $0-42$ & Blend (oregano, anise and citrus peel) & $0-500$ \\
\hline Paraskeuas et al [74] & 150 & $0-42$ & Blend (men, ane, eug) & $0-150$ \\
\hline Ri et al [75] & 180 & $0-42$ & Oregano EOs & $0-150$ \\
\hline Altop et al [28] & 375 & $0-42$ & Sweet gum EOs & $0-162.2$ \\
\hline Giannenas et al [76] & 320 & $0-42$ & Blend ( $\beta$-car, men) & $0-500$ \\
\hline Hosseini and Meimandipour [77] & 150 & $0-42$ & Thyme EOs & $0-80$ \\
\hline Mohiti-Asli and Ghanaatparast-Rashti [78] & 200 & $0-42$ & Blend (oregano, anise and citrus peel) and oregano & $0-500$ \\
\hline Pirgozliev et al [7] & 256 & $0-21$ & Blend (cin, car, cap) & $0-100$ \\
\hline Park and Kim [38] & 360 & $0-42$ & Blend (thy, eug, pip) & $0-300$ \\
\hline Reis et al [52] & 240 & $0-42$ & Blend (car, thy, cin) & $0-500$ \\
\hline Abdel-Wareth et al [25] & 384 & $0-35$ & peppermint EOs and men & $0-222$ \\
\hline Attia et al [11] & 216 & $0-36$ & Blend (cin, thy) & $0-150$ \\
\hline Galli et al [53] & 135 & $0-44$ & Blend (car, thy, cin) & $0-100$ \\
\hline Nouri [79] & 300 & $0-14$ & mint EOs, thyme EOs, cinnamon EOs & $0-55$ \\
\hline Placha et al [80] & 96 & $0-28$ & Thyme EOs & $0-100$ \\
\hline
\end{tabular}

EOs, essential oils; thy, thymol; ane, anethole; car, carvacrol; cin, cinnamaldehyde; 1,8-cin, 1,8-cineole; zin, zingiberene; $\beta$-ses, $\beta$-sesquiphellandrene; sab, sabinene; ar-cur, ar-curcumene; $\beta$-bis, $\beta$-bisabolene, eug, eugenol; pip, piperine; men, menthol; cum, cuminaldehyde; $\beta$-car, $\beta$-caryophillene; cap, capsicum oleoresin.

of their specific composition. The EOs inclusion ranged from 0 (control) to $750 \mathrm{mg} / \mathrm{kg}$ and averaged at $112( \pm 149) \mathrm{mg} / \mathrm{kg}$. The EOs included in the database were given in specific major component of EOs (thymol, carvacrol, cinnamaldehyde), a blend of EOs including as commercial EOs (thymol, carvacrol, eugenol, piperine, cinnamaldehyde, anethole, menthol, $\mathrm{y}$-terpinene, limonene, $\mathrm{a}$-turmerone, $\mathrm{p}$-cymene, camphor, a-pipene, d-limonene, linalool), or given as EOs extracted from specific plant sources (oregano EOs, thyme EOs, mint
EOs, rosemary EOs, star anise EOs, cinnamon EOs, basil EOs, caraway EOs, laurel EOs, lemon EOs, sage EOs, tea EOs, turmeric EOs, clove EOs). Antibiotics used as a positive control in the studies were salinomycin, zinc bacitracin, avilamycin, chlortetracycline, virginiamycin, and commercial anticoccidial (Cygro).

\section{Statistical analysis}

Data tabulated in the database were subjected to a mixed 
Table 2. Descriptive statistics of nutrient specifications used in meta-analysis

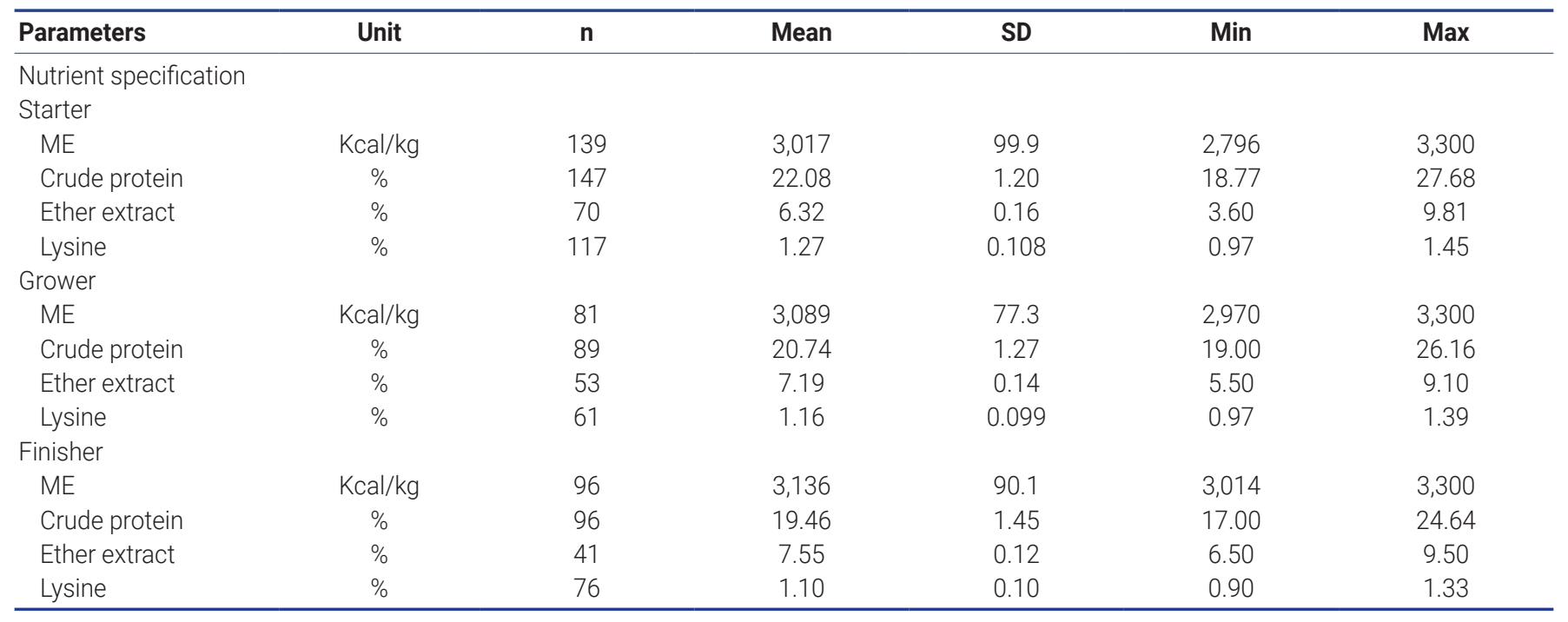

SD, standard deviation; Max, maximum; Min, minimum; ME, metabolizable energy.

model analysis according to St-Pierre [18]. The SAS software was employed to analyze the data following the PROC MIXED procedure (SAS Studio 3.8, University Edition, 2018). The EOs were considered as fixed effects whereas the different studies were taken into account as random effects. The model applied was:

$$
Y_{i j}=B_{0}+B_{1} X_{i j}+B_{2} X_{i j}^{2}+s_{i}+b_{i} X_{i j}+e_{i j}
$$

where $Y_{i j}=$ the expected output for dependent variable $Y$ at level $j$ from the variable $X$ as a continuous variable in the study $i, B_{0}=$ overall intercept across experiments (fixed effect), $B_{1}=$ linear regression coefficient of $Y$ on $X$ (fixed effect), $B_{2}$ = quadratic regression coefficient of $Y$ on $X$ (fixed effect), $X_{\mathrm{ij}}$ $=$ value of the continuous predictor variable $X$ (doses of EOs administration), $s_{\mathrm{i}}=$ random effect of experiment $i, b_{i}=$ random effect of experiment $i$ on the regression coefficient of $Y$ on $X$ in experiment $i$ and $e_{i j}=$ the residual error. In the statement CLASS, the "study" variable was declared. Data were weighted by the number of replicates in each study. Additionally, an unstructured variance - covariance matrix (type $=$ un) was performed at the random effect part of the model to avoid a positive correlation between intercepts and slopes [18]. Regarding the continuous predictor, p-values for intercepts and slopes, Akaike's information criterion, and root mean square error were used for model statistics [22,23]. Meanwhile, to test the effectiveness of type of EOs, we categorized the EOs according to their major compound and antimicrobial activity following the classification and justification from the evidence of previous reports $[3,24]$. Here, the EOs groups possible to compare were thymol-based compound (thy-BC), carvacrol-based compound (car-BC), cinnamaldehyde-based compound (cin-BC), and menthol- based compound (men-BC). Treatments containing one or more combinations of these compounds except for menthol were grouped as EOs-Blend 1 (EOB 1) and the other containing multiple compound of terpenoids (linalool, geraniol, thujanol, borneol, menthol, citronellol, terpineol) was grouped as EOs-Blend 2 (EOB 2). We did not group a single compound from terpenoids except for menthol because the sample size was too small. As a result, there were eight treatment groups consisting of six EOs categories as moderating variables, AGP group, and control group. The categorical analysis was performed according to the following model:

$$
Y_{i j}=\mu+S_{i}+\tau_{j}+S \tau_{i j}+e_{i j}
$$

where $Y_{i j}=$ the expected output for dependent variable $Y, \mu$ $=$ overall mean, $S_{i}=$ random effect of $i$ study, $\tau_{j}=$ fixed effect of the $j$ level, $S \tau_{i j}=$ random interaction between $i$ study and the $j$ level, and $e_{i j}=$ residual error. A significant effect was declared at $\mathrm{p}<0.05$ or there is a tendency when the $\mathrm{p}$-value was between 0.05 and 0.10 . Comparison among the experimental group was conducted with least square means and adjusted with Tukey's test.

\section{RESULTS}

The dose of EOs administration on productive performance, nutrient digestibility, cecal microbes, and serum metabolites of broiler chickens

The regression equations between the dose of EOs and broiler productive performance, nutrient digestibility, intestinal profile, and serum metabolites are presented in Table 4 and 5 . The productive parameters (BWG and final BW) represented a linear increase where ADFI and FCR showed a linear 
Table 3. Descriptive statistics of the variables used in meta-analysis

\begin{tabular}{|c|c|c|c|c|c|c|}
\hline Parameters & Unit & $\mathbf{n}$ & Mean & SD & Min & Max \\
\hline \multicolumn{7}{|l|}{ Production performance } \\
\hline Age & $d$ & 163 & 36.0 & 9.4 & 14.0 & 46.0 \\
\hline Body weight & $g$ & 152 & 2,095 & 731.6 & 525.1 & 3,436 \\
\hline Feed intake & $\mathrm{g} /$ period & 149 & 3,525 & $1,334.5$ & 757.6 & 5,735 \\
\hline Feed conversion ratio & g feed/g gain & 149 & 1.69 & 0.21 & 0.71 & 2.14 \\
\hline Body weight gain & $\mathrm{g} / \mathrm{bird} / \mathrm{d}$ & 152 & 56.48 & 13.73 & 25.01 & 83.90 \\
\hline Average daily feed intake & $\mathrm{g} / \mathrm{d}$ & 149 & 95.80 & 25.31 & 36.07 & 152.0 \\
\hline \multicolumn{7}{|l|}{ Nutrient digestibility } \\
\hline Dry matter & $\%$ & 23 & 71.20 & 6.56 & 56.20 & 79.01 \\
\hline Crude protein & $\%$ & 30 & 72.45 & 10.51 & 45.30 & 86.50 \\
\hline Ether extract & $\%$ & 20 & 85.28 & 6.66 & 73.30 & 94.80 \\
\hline \multicolumn{7}{|l|}{ Relative organ weight } \\
\hline Carcass & $\% \mathrm{BW}$ & 34 & 71.37 & 0.922 & 59.48 & 78.85 \\
\hline Breast meat & $\% \mathrm{BW}$ & 10 & 28.06 & 13.86 & 14.81 & 45.22 \\
\hline Abdominal fat & $\% \mathrm{BW}$ & 23 & 1.76 & 0.62 & 0.66 & 2.83 \\
\hline Gizzard & $\% \mathrm{BW}$ & 26 & 1.98 & 0.190 & 0.63 & 3.40 \\
\hline \multicolumn{7}{|l|}{ Lymphoid organ weight } \\
\hline Liver & $\% \mathrm{BW}$ & 57 & 2.43 & 0.088 & 1.73 & 5.25 \\
\hline Spleen & $\% \mathrm{BW}$ & 44 & 0.20 & 0.35 & 0.08 & 1.79 \\
\hline Bursa of Fabricius & $\%$ BW & 31 & 0.19 & 0.03 & 0.10 & 0.27 \\
\hline Pancreas & $\%$ BW & 38 & 0.45 & 0.50 & 0.20 & 1.75 \\
\hline \multicolumn{7}{|l|}{ Cecal microbes } \\
\hline Escherichia coli & Log CFU/g & 26 & 7.03 & 1.20 & 5.11 & 9.56 \\
\hline Lactobacillus & Log CFU/g & 30 & 7.33 & 1.91 & 1.97 & 9.81 \\
\hline Coliform & Log CFU/g & 21 & 7.19 & 0.97 & 5.49 & 8.40 \\
\hline \multicolumn{7}{|l|}{ Intestinal morphology } \\
\hline Villus height & $\mu \mathrm{m}$ & 29 & 858.0 & 465.1 & 286.0 & 1752 \\
\hline Villus width & $\mu \mathrm{m}$ & 14 & 148.7 & 87.7 & 80.5 & 404.4 \\
\hline Crypth depth & $\mu \mathrm{m}$ & 29 & 154.9 & 15.92 & 60.0 & 404.0 \\
\hline Height/depth & $\mu \mathrm{m}$ & 12 & 5.35 & 2.44 & 2.67 & 9.10 \\
\hline \multicolumn{7}{|l|}{ Serum metabolites } \\
\hline $\lg G$ & $\mu \mathrm{g} / \mathrm{mL}$ & 13 & 13.62 & 11.75 & 4.03 & 39.41 \\
\hline Triglycerides & $\mathrm{mg} / \mathrm{dL}$ & 39 & 92.02 & 46.81 & 28.60 & 178.0 \\
\hline Cholesterol & $\mathrm{mg} / \mathrm{dL}$ & 44 & 138.80 & 80.82 & 42.00 & 443.8 \\
\hline $\mathrm{HDL}$ & $\mathrm{mg} / \mathrm{dL}$ & 18 & 78.42 & 25.21 & 50.20 & 139.9 \\
\hline LDL & $\mathrm{mg} / \mathrm{dL}$ & 15 & 79.35 & 77.80 & 33.80 & 273.0 \\
\hline Glucose & $\mathrm{mg} / \mathrm{dL}$ & 31 & 249.9 & 5.32 & 189.3 & 320.2 \\
\hline Albumin & $\mathrm{mg} / \mathrm{dL}$ & 15 & 2.16 & 0.81 & 0.92 & 3.70 \\
\hline Protein & $\mathrm{mg} / \mathrm{dL}$ & 25 & 4.35 & 2.03 & 1.36 & 7.60 \\
\hline Globulin & $\mathrm{mg} / \mathrm{dL}$ & 12 & 2.19 & 0.633 & 1.70 & 3.80 \\
\hline
\end{tabular}

SD, standard deviation; Max, maximum; Min, minimum; IgG, immunoglobulin G; HDL, high density lipoprotein; LDL, low density lipoprotein.

decrease $(\mathrm{p}<0.001)$ with increasing EOs doses except for feed intake that showed a quadratic model $(\mathrm{p}<0.001)$. Similarly, positive effects of EOs inclusion were also detected on increasing apparent DM, CP, and EE digestibility with a linear pattern $(\mathrm{p}<0.001)$ which may be a factor promoting the increase in BWG. Administration of EOs also increased carcass and gizzard and decreased abdominal fat percentage relative to BW $(\mathrm{p}<0.01)$ and some of the lymphoid organ weight such as the spleen, bursa fabricius (BF), and pancreas although the pattern of spleen and BF followed quadratic relationship $(\mathrm{p}<0.05)$. To a lesser extent, liver tended to show a quadratic pattern $(\mathrm{p}=0.054)$.
Another beneficial effect of supplementing EOs in the broiler diet was shown by linearly increasing $(\mathrm{p}<0.001)$ Lactobacillus and suppressing Escherichia coli (E. coli) population in the cecum. The population of coliform also linearly increased $(\mathrm{p}=0.03)$ although the effect was smaller. Villus height of the broiler intestine increased as the EOs doses increased $(p<0.001)$ but the villus width showed a contrary result ( $p=0.007)$. A different response was observed on crypt depth which was affected quadratically by EOs administration $(p<0.05)$ while the height/depth criterion decreased linearly $(\mathrm{p}<0.05)$.

Responses of serum metabolites to dietary EOs were posi- 
Table 4. Regression equations on the effect of essential oils dose (in $\mathrm{mg} / \mathrm{kg}$ of diet) on production performance, nutrient digestibility, and organ weight of broiler chickens

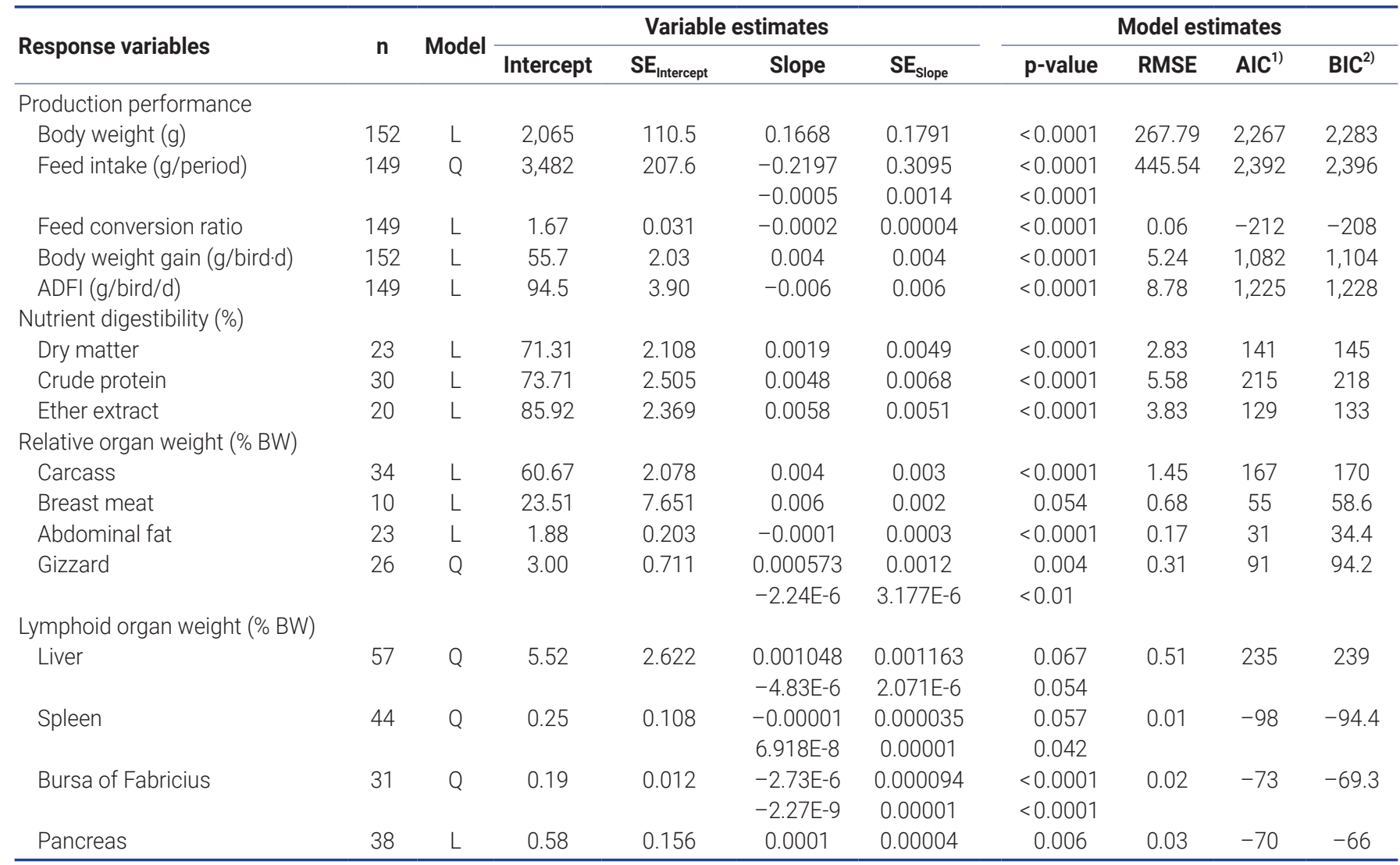

SE, standard error; RMSE, root mean square error; AIC, akaike information criterion; BIC, bayesian information criterion; L, linear; $Q$, quadratic; $A D F I$, average daily feed intake; BW, body weight.

${ }^{1)} \mathrm{AIC}$ is an estimator of the relative quality of statistical models for a given set of data (smaller is better).

${ }^{2)} \mathrm{BIC}$ is an estimator of a probability of a model being true (smaller is better).

tive, as the EOs linearly reduced low density lipoprotein (LDL) concentration $(\mathrm{p}<0.01)$ and concomitantly increased high density lipoprotein (HDL), glucose, protein, and globulin concentrations at a linear pattern $(\mathrm{p}<0.01)$. The concentration of triglycerides and cholesterol linearly and quadratically decreased in response to elevating the dose of EOs ( $\mathrm{p}<0.01)$. There was no effect of EOs inclusion on immunoglobulin metabolite $(\mathrm{IgG})$ as shown in Table $5(\mathrm{p}=0.169)$.

\section{Comparison of the effectiveness of the type of EOs and AGP on broiler performance}

The effectiveness of EOs to replace the use of AGP in terms of improving broiler performance was examined and the comparison results are presented in Table 6 and 7. There was marginal evidence on the effect of EOs administration on daily weight gain (BWG) and final BW of broiler chickens whereas EOB 1 increased $(\mathrm{p}<0.05)$ the BWG and final BW $(\mathrm{p}<0.05)$ by $8.52 \%$ and $11.17 \%$, respectively compared to those of Con and $\mathrm{AB}$ groups. The FCR significantly decreased $(\mathrm{p}<0.001)$ by employing all types of EOs (Thy-BC, Car-BC, Cin-BC, Men-BC, EOB 1, and EOB 2) whereas the Car-BC showed the largest reduction (7.14\%) in comparison with the control group. There was no effect $(\mathrm{p}>0.05)$ of $\mathrm{AB}$ on FCR. The inclusion of EOs in this study did not influence ( $\mathrm{p}$ $=0.956)$ ADFI and cumulative FI $(p=0.967)$. Type of EOs also failed to increase the digestibility of $\mathrm{DM}, \mathrm{CP}$, and $\mathrm{EE}$ compared with the use of AGP and that did not receive any additive ( $p>0.10)$. Cin- $B C$ treatment tended to increase $(p=$ $0.067)$ carcass weight by $5.67 \%$ while Thy- $\mathrm{BC}$ group tended to increase $(\mathrm{p}=0.071)$ relative weight of liver (Table 7).

The population of $E$. coli significantly reduced $(\mathrm{p}<0.01)$ with Cin-BC and EOB 1 treatments by $8.88 \%$ and $7.76 \%$, respectively while the population of Coliform and Lactobacillus did not differ among the treatment groups $(\mathrm{p}>0.10)$. There was no difference in the intestinal morphology of broiler chickens in response to the administration of AGP or type of EOs ( $p>0.10)$. Furthermore, due to relatively large variation of the data of immunoglobulin concentration and serum metabolites parameters, most of these parameters including the concentration of IgG, triglycerides, cholesterol, HDL, and glucose did not change with the application of EOs in comparison to $\mathrm{AB}$ and control groups ( $\mathrm{p}>0.10)$. 
Table 5. Regression equations on the effect of essential oils dose (in $\mathrm{mg} / \mathrm{kg}$ of diet) on cecal microbes, intestinal morphology, and serum metabolites profile of broiler chickens

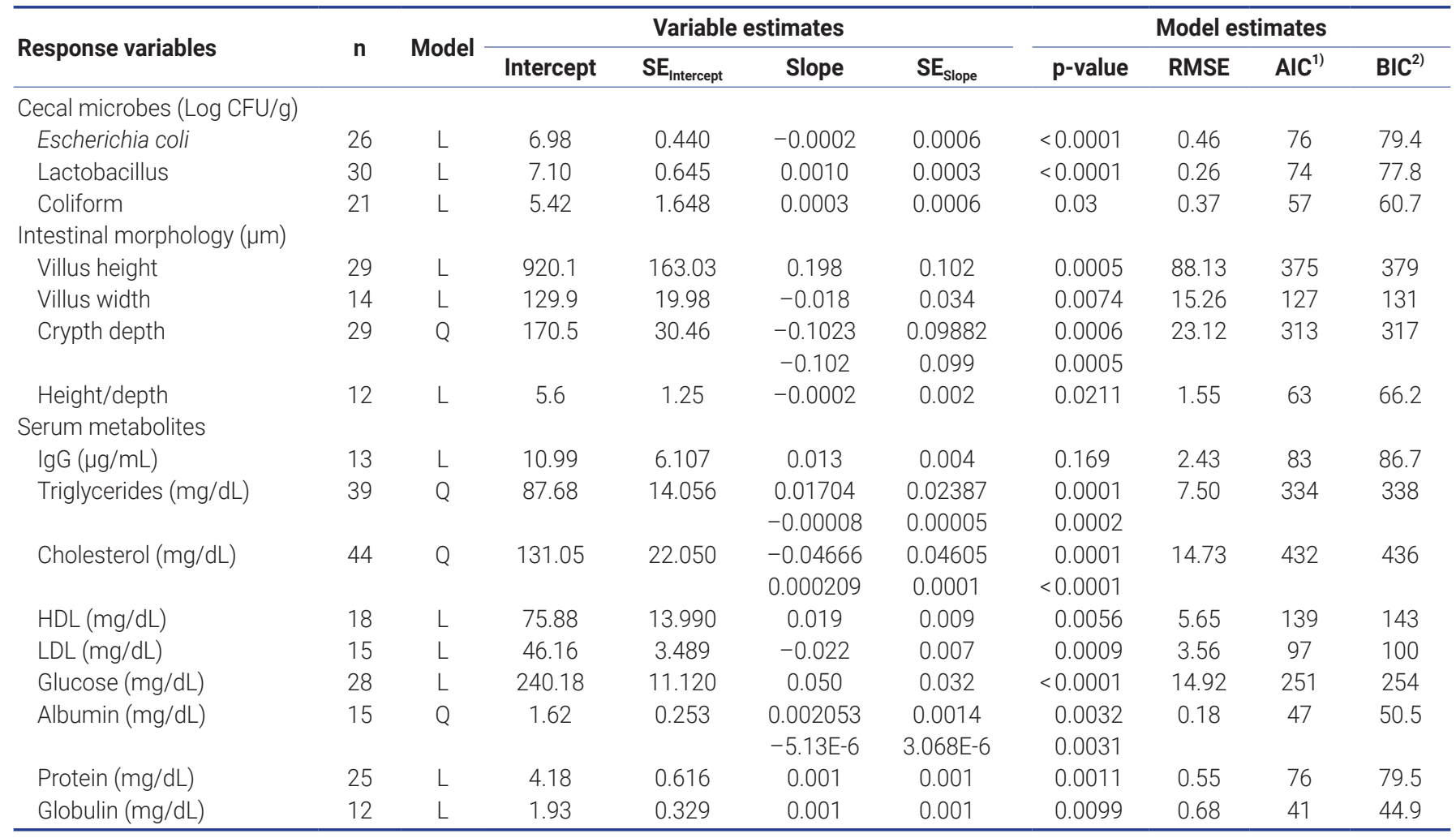

SE, standard error; RMSE, root mean square error; AIC, akaike information criterion; BIC, bayesian information criterion; CFU, colony forming unit; IgG, Immunoglobulin G; HDL, high density lipoprotein; LDL, low density lipoprotein.

${ }^{1)} \mathrm{AIC}$ is an estimator of the relative quality of statistical models for a given set of data (smaller is better).

2) $\mathrm{BIC}$ is an estimator of a probability of a model being true (smaller is better).

Table 6. Effect of antibiotics and EOs administration on production performance, nutrient digestibility, and organ weight of broiler chickens

\begin{tabular}{|c|c|c|c|c|c|c|c|c|c|c|c|c|}
\hline \multirow{2}{*}{ Response variables } & \multirow{2}{*}{ Unit } & \multirow{2}{*}{$\mathbf{n}$} & \multirow{2}{*}{ Con $^{1)}$} & \multirow{2}{*}{$A B^{1)}$} & \multicolumn{6}{|c|}{ Type of EOs bioactive compounds ${ }^{1)}$} & \multirow{2}{*}{ SEM } & \multirow{2}{*}{ p-value } \\
\hline & & & & & Thy-BC & Car-BC & Cin-BC & Men-BC & EOB 1 & EOB 2 & & \\
\hline \multicolumn{13}{|l|}{ Production performance } \\
\hline Body weight & g & 152 & $2,042^{b}$ & $2,075^{a b}$ & $1,945^{\mathrm{c}}$ & $2,174^{\mathrm{ab}}$ & $2,096^{\mathrm{ab}}$ & $2,120^{\mathrm{ab}}$ & $2,270^{a}$ & $2,082^{\mathrm{ab}}$ & 59.34 & 0.080 \\
\hline Feed Intake & g & 149 & 3,476 & 3,487 & 3,213 & 3,440 & 3,451 & 3,445 & 3,718 & 3,480 & 109.33 & 0.304 \\
\hline Feed conversion ratio & $\mathrm{g}$ feed/g gain & 149 & $1.68^{\mathrm{a}}$ & $1.66^{\mathrm{ab}}$ & $1.62^{\mathrm{b}}$ & $1.56^{\mathrm{c}}$ & $1.62^{b}$ & $1.60^{\mathrm{b}}$ & $1.64^{\mathrm{b}}$ & $1.65^{\mathrm{b}}$ & 0.02 & $<0.001$ \\
\hline Body weight gain & $\mathrm{g} / \mathrm{bird} / \mathrm{d}$ & 152 & $55.05^{b}$ & $55.71^{b}$ & $53.96^{\circ}$ & $57.87^{\mathrm{ab}}$ & $57.72^{\mathrm{ab}}$ & $56.73^{b}$ & $59.74^{\mathrm{a}}$ & $56.32^{\mathrm{b}}$ & 1.11 & 0.059 \\
\hline \multicolumn{13}{|l|}{ Nutrient digestibility } \\
\hline Dry matter & $\%$ & 23 & 70.85 & 71.79 & 69.57 & - & 73.64 & 66.58 & 73.6 & 73.28 & 1.37 & 0.472 \\
\hline Crude protein & $\%$ & 30 & 72.41 & 74.46 & 73.13 & - & 79.38 & 79.65 & 75.51 & 76.19 & 1.92 & 0.635 \\
\hline Ether extract & $\%$ & 20 & 84.98 & 83.86 & 86.61 & - & 90.88 & 87.22 & 90.07 & 83.46 & 1.49 & 0.329 \\
\hline \multicolumn{13}{|l|}{ Relative organ weight } \\
\hline Carcass & $\% B W$ & 34 & $69.36^{b}$ & $69.88^{b}$ & $71.19^{a b}$ & $69.84^{b}$ & $73.29^{\mathrm{a}}$ & $69.69^{b}$ & $69.29^{b}$ & $67.73^{b}$ & 0.91 & 0.067 \\
\hline Abdominal fat & $\% B W$ & 23 & 1.89 & 2.13 & 1.96 & - & 1.81 & - & 2.01 & 1.57 & 0.13 & 0.173 \\
\hline \multicolumn{13}{|l|}{ Lymphoid organ weight } \\
\hline Liver & $\% B W$ & 57 & $2.32^{b}$ & $2.2^{b}$ & $2.58^{a}$ & $2.34^{\mathrm{ab}}$ & $2.11^{b}$ & $2.11^{b}$ & $2.09^{b}$ & $2.5^{\mathrm{ab}}$ & 0.09 & 0.071 \\
\hline Spleen & $\% B W$ & 44 & 0.24 & 0.26 & 0.24 & 0.25 & 0.24 & 0.25 & 0.25 & 0.24 & 0.05 & 0.914 \\
\hline Bursa of Fabricius & $\% B W$ & 31 & 0.19 & 0.19 & 0.21 & 0.19 & 0.20 & - & 0.19 & - & 0.01 & 0.178 \\
\hline Pancreas & $\% B W$ & 38 & 0.58 & 0.57 & 0.62 & - & 0.59 & 0.58 & 0.54 & 0.62 & 0.08 & 0.213 \\
\hline
\end{tabular}

EOs, essential oils; SEM, standard error of means; BW, body weight.

1) Con, control; $A B$, antibiotics; Thy-BC, thymol-based compound; Car-BC, carvacrol-based compound; Cin-BC; cinnamaldehyde-based compound; Men-BC, menthol-based compound; EOB 1, essential oils blend containing one of more of thymol, carvacrol, and cinnamaldehyde compounds; EOB 2, essential oils blend based on terpenoids group (linalool, geraniol, thujanol, borneol, menthol, citronnillol, terpineol).

${ }^{a-c}$ Value with different letters differ at $p<0.05$. 
Table 7. Effect of antibiotics and EOs administration on cecal microbes, intestinal morphology, and serum metabolites profile of broiler chickens

\begin{tabular}{|c|c|c|c|c|c|c|c|c|c|c|c|c|}
\hline \multirow{2}{*}{ Response variables } & \multirow{2}{*}{ Unit } & \multirow{2}{*}{$\mathbf{n}$} & \multirow{2}{*}{ Con $^{1)}$} & \multirow{2}{*}{$A B^{1)}$} & \multicolumn{6}{|c|}{ Type of EO bioactive compounds ${ }^{1)}$} & \multirow{2}{*}{ SEM } & \multirow{2}{*}{ p-value } \\
\hline & & & & & Thy-BC & Car-BC & Cin-BC & Men-BC & EOB 1 & EOB 2 & & \\
\hline \multicolumn{13}{|l|}{ Cecal microbes } \\
\hline Escherichia coli & Log CFU/g & 26 & $7.09^{\mathrm{a}}$ & $7.18^{\mathrm{a}}$ & $6.92^{\mathrm{ab}}$ & $6.91^{\mathrm{ab}}$ & $6.46^{b}$ & $6.82^{\mathrm{ab}}$ & $6.54^{b}$ & $6.95^{\mathrm{ab}}$ & 0.24 & $<0.01$ \\
\hline Lactobacillus & Log CFU/g & 30 & 7.08 & 7.21 & 7.35 & 7.16 & 7.32 & 7.13 & 7.34 & 7.82 & 0.35 & 0.501 \\
\hline Coliform & Log CFU/g & 21 & 5.49 & 5.8 & 5.32 & 5.54 & - & - & - & 5.73 & 0.21 & 0.559 \\
\hline \multicolumn{13}{|l|}{ Intestinal morphology } \\
\hline Villus height & um & 29 & 914 & 960 & 1,149 & 966 & - & - & 929 & 1143 & 81.21 & 0.234 \\
\hline Crypth depth & um & 29 & 171 & 174 & 192 & 166 & - & - & $155^{\mathrm{b}}$ & 180 & 14.13 & 0.153 \\
\hline Heigh/depth & um & 12 & 5.26 & 5.59 & - & 5.85 & - & - & 6.39 & 4.16 & 0.71 & 0.928 \\
\hline \multicolumn{13}{|l|}{ Serum metabolites } \\
\hline $\lg G$ & $\mu \mathrm{g} / \mathrm{mL}$ & 13 & 10.98 & 10.63 & 20.77 & 11.11 & - & - & 13.14 & - & 3.26 & 0.202 \\
\hline Tryglicerides & $\mathrm{mg} / \mathrm{dL}$ & 39 & 87.95 & 86.2 & 85.27 & 75.32 & 86.64 & - & 84.77 & 90.12 & 7.46 & 0.573 \\
\hline Cholesterol & $\mathrm{mg} / \mathrm{dL}$ & 44 & 131.7 & 128.6 & 138.6 & 135.1 & 129.6 & - & 135.2 & 130.3 & 12.18 & 0.976 \\
\hline HDL & $\mathrm{mg} / \mathrm{dL}$ & 18 & 75.02 & 80.39 & 83.09 & 81.62 & - & - & - & 78.18 & 5.94 & 0.434 \\
\hline LDL & $\mathrm{mg} / \mathrm{dL}$ & 15 & $48.08^{a}$ & $41.08^{b}$ & $35.79^{\mathrm{bc}}$ & $39.49^{b}$ & - & - & - & $43.9^{\mathrm{ab}}$ & 1.67 & $<0.05$ \\
\hline Glucose & $\mathrm{mg} / \mathrm{dL}$ & 28 & 236 & 249 & 245 & - & 241 & - & 239 & 255 & 5.32 & 0.224 \\
\hline Albumin & $\mathrm{mg} / \mathrm{dL}$ & 15 & $1.59^{b}$ & $1.59^{b}$ & $1.43^{b}$ & - & $2.05^{a}$ & - & $1.53^{b}$ & $1.69^{b}$ & 0.21 & 0.061 \\
\hline Protein & $\mathrm{mg} / \mathrm{dL}$ & 25 & $4.01^{b}$ & $3.92^{\mathrm{b}}$ & $4.05^{b}$ & - & $5.36^{a}$ & - & $3.97^{b}$ & $4.29^{b}$ & 0.41 & 0.059 \\
\hline Globulin & $\mathrm{mg} / \mathrm{dL}$ & 12 & $1.72^{b}$ & $1.77^{\mathrm{b}}$ & $2.07^{b}$ & - & $2.84^{a}$ & - & $1.81^{b}$ & - & 0.16 & $<0.05$ \\
\hline
\end{tabular}

EOs, essential oils; SEM, standard error of means; CFU, colony forming unit; IgG, immunoglobulin G; HDL, high density lipoprotein; LDL, low density lipoprotein.

1) Con, control; $A B$, Antibiotics; Thy-BC, thymol-based compound; Car-BC, carvacrol-based compound; Cin-BC; cinnamaldehyde-based compound; Men-BC, menthol-based compound; EOB 1, essential oils blend containing one of more of thymol, carvacrol, and cinnamaldehyde compounds; EOB 2, essential oils blend based on terpenoids group (linalool, geraniol, thujanol, borneol, menthol, citronnillol, terpineol)

${ }^{a-c}$ Value with different letters differ at $p<0.05$

However, a positive effect was observed on significantly reduced ( $\mathrm{p}<0.05$ ) LDL concentration by $14.55 \%$ and $17.86 \%$, respectively using $\mathrm{AB}$ and Car- $\mathrm{BC}$ when compared to the control group. Globulin concentration increased $(\mathrm{p}<0.05)$ by $39.43 \%$ with $\mathrm{Cin}-\mathrm{BC}$ treatment while this treatment also tended to increase $(\mathrm{p}<0.1)$ the albumin and protein concentration of the serum metabolite.

\section{DISCUSSION}

Empirical works evaluating the efficacy of EOs bioactive compounds on broiler performance are abundant, which of those have been regularly reviewed $[3,4,17]$. However, no study so far has attempted to quantitatively summarize the effect of EOs on broiler performance by employing a metaanalysis approach. An increase in final BW and a concomitant reduction in FCR of broiler chickens suggested that EOs inclusion promotes more efficient nutrient utilization. This evidence was largely supported by numerous studies with different in their sources and types of EOs, such as AbdelWareth et al [25] who used peppermint and menthol, Nameghi et al [26] who used blend EOs from thyme, peppermint, and eucalyptus, and Hashemipour et al [27] who used thymol + carvacrol. Although the effects of EOs on performance are obviously variable within the plant sources, the beneficial effects are apparently identical among different sources and types, and these are dose-dependent. Altop et al [28] revealed a significant quadratic pattern on BW and FCR when using sweetgum (Liquidambar orientalis Mill.) leaves that contained y- Terpinen-4-ol and y-terpinene as major components, with an optimum dose of $80 \mathrm{mg} / \mathrm{kg}$. In regard to feed intake, available literatures suggested that EOs effect can be either stimulate or suppress feed palatability, depending on their level, types, and bird age [28-30].

Inconclusive findings among previous studies underlying the mechanism on how dietary EOs could improve broiler performance are at least partially overcome in this current meta-analysis. Such an effect can be attributed to the increasing nutrient digestibility, gizzard weight (capacity), and villus height as shown in the relationship between the dose of EOs and response variables. Previously, similar results were reported that EOs inclusion improved apparent ileal digestibility of nutrients at 21,35 , and $42 \mathrm{~d}$ of age [9]. Little is known about the effect of EOs on enzyme secretion at the early age of broiler because, to our knowledge, there is no study examining nutrient digestibility at the age of less than $14 \mathrm{~d}$ in regard to EOs incorporated-diet. Thus, it was speculated that EOs may show a lack of ability to promote enzyme secretion in the pre-starter or starter phase of broiler because in this period, indigenous enzyme secretion is very low [31]. It has been recognized that increasing nutrient digestibility primarily occurred on adult birds, apparently due to the improvement of small intestine morphology and microbial balance, and possibly because of the stimulating effect on an 
increase in bile acids and digestive and pancreatic enzymes secretion [30,32].

Furthermore, most studies supported the available hypothesis that the effect on enzyme was more pronounced in adult birds. For instance, there was a linear increase in trypsin, lipase, and protease activities on the 24-d broiler intestine fed with EOs containing-phytogenic [27]. Similarly, higher activity and production of the pancreatic and digestive enzyme were exhibited on birds received thymol [32] or oregano EOs [30] while Masouri et al [33] also confirmed an increase in digestive juices which has antimicrobial effects by supplementing EOs. In addition to the positive effects aforementioned, it is primarily important to further investigate a factor related to enzyme secretion enhancement by supplementing EOs because few studies also reported absence effect on that [34] which may be due to difference in bioactive compounds, animal age, hygiene, diet type, and also environmental factors [27].

As confirmed in this study, the abundance of Lactobacillus increased while the population of E. coli decreased, whereas this result is in line with previous studies that reported similar results $[26,35]$. It has been widely known that EOs bioactive compounds are broad-spectrum antibacterial, antiviral, and antifungal. Using $45 \mathrm{EOs}$, Chao et al [36] found that all of these compounds effectively inhibited eight genera of bacteria with different degrees of inhibitory effects. Some were more sensitive to either gram-negative or gram-positive bacteria and some others were effective for both types of bacteria, depending on the variation in chemical compositions of the EOs. Interestingly, the relationship between major and trace components of the EOs was also varied among others which can be synergistic, additive, or antagonistic $[37,38]$.

It is generally accepted that there is more than one mode of action regarding their antibacterial role although the specific mechanism is not clear. In regard to their mode of action, EOs bioactivity can be recognized from their multiple benefits such as antimicrobial, antioxidant, immunomodulator, and anti-inflammatory properties [3]. Available explanations suggested that the antimicrobial effect is largely due to the hydrophobicity characteristics which allow the substances to disturb the permeability of the cell wall of bacteria and its mitochondria. EOs components such as carvacrol, eugenol (2-methoxy-4-(2-propenyl)phenol), and thymol, for example, can depolarize the cytoplasmic membrane of gram-negative bacteria by disintegrating the outer membrane of targeted bacteria [39]. Alteration of intestinal flora is one of the important roles of EOs to act as growth-promoting additive. More recently, microbiome study in the cecal part of broiler confirmed an enrichment of phyla Bacteroidetes and genera Alistipes which play at promoting animal growth by supplementing EOs [40].

In addition to the antimicrobial effect, they are also able to stimulate digestive enzyme secretion and activity and increase bile synthesis that can positively increase the digestibility of nutrients. Moreover, many of EOs constituents showed to improve antioxidant status especially EOs extracted from aromatic plants. Their antioxidant activity was also related to the ability of EOs to reduce cell proliferation and act as antiinflammatory properties. It was reported that EOs could scavenge reactive oxygen species from bacterial phagocytosis process, resulting in the reduction of tissue oxidative damage and inflammation [8].

An increase in villus height in response to dietary EOs was supported by other studies [10,41] but it was not sufficient to elucidate the mode of action. Nevertheless, Hamedi et al [42] reported there was no effect on villus height and crypt depth by incorporating EOs from peppermint and thyme. Because there is limited information on that, several authors suggested that it might be a result of toxins reducing effect in the gastrointestinal tract because of the modulation of microflora [43]. Also, EOs can enhance the mature enterocytes that can improve absorption capacity due to an increase in the villus height and decrease the crypt depth [26].

EOs also exhibited a positive effect on the organ composition of broiler chickens. This is consistent with numerous studies using different EOs sources $[9,25,26]$. It is well explained that active components of EOs such as carvacrol, thymol, menthol, and p-cymene were involved in the lipids metabolism, particularly on serum cholesterol [44]. It was found that phenol and flavonoids compounds of EOs reduced rate-limiting enzyme involved in cholesterol synthesis, 3 hydroxy-3-methylglutaryl coenzyme A reductase because it is a key enzyme for cholesterol production [45]. As a result, not only less fat accumulation and more carcass portion, but also a positive correlation to the decreased of cholesterol, triglycerides, and LDL concentrations of serum metabolites were produced in this study. At the same time, blood protein, globulin, glucose, and albumin also increased. These were in agreement with several experiments in which dietary EOs extracted from a variety of plants reduced cholesterol levels [46], and increased blood albumin, globulin, and protein $[47,48]$. EOs supplementation also affected lymphoid organ weight. Previous studies also demonstrated that EOs blend increased $\mathrm{BF}$ and thymus [26,49] but in contrast with Rahimi et al [50]. The effect of EOs on immune function of broiler is apparently weaker compared to its effects as a gut modulator, enzyme stimulator, and growth promoter. This is supported that by the fact that the immunoglobulin concentration of IgG was not affected by the EOs administration in this study.

To better understand which type of EOs affected the broiler performance, analysis of moderator variables that may affect the magnitude of EOs was conducted by grouping the EOs based on references evaluating the degree of antimicrobial 
effects. Accordingly, this study found that EOs blend containing more than two combination of thymol, carvacrol, cinnamaldehyde, and menthol had a greater effect to increase $\mathrm{ADG}$ and final BW of broiler chickens than other type of EOs although the effect was not substantial. In agreement with this study, some previous reports showed that combination of thymol and cinnamaldehyde [36,51] or thymol, carvacrol, and cinnamaldehyde $[52,53]$ had greater antimicrobial effect than antibiotics and significantly increased broiler productive performance. In addition, all types of EOs bioactive compounds also significantly reduce FCR compared to the control and antibiotics groups. This result was also in agreement with previous experiments $[54,55]$ who found that the main effect of antibiotics and EOs was more significant on lowering FCR where the effect on BWG and final BW was rather low. Likewise, in this study EOs promoted higher population of Lactobacillus and lower population of $E$. coli than antibiotics which also reasonably increase feed efficiency. This finding suggested that by using EOs, more economic profit seems to be earned as feed conversion efficiency is of the most important indicator in the broiler industry, in the condition when the relative value of EOs products are similar with AGP. Accordingly, investigations on the economic aspect of various conditions are demanding.

\section{CONCLUSION}

The present meta-analysis confirms that there are positive effects on broiler productive performance as the inclusion levels of EOs increase, regardless of type of components used. Across all studies, the growth-promoting effect of EOs is strongly related to their strategic role in many metabolic pathways as antimicrobial, antioxidant, and anti-inflammatory agents resulting in an increase in nutrient digestibility, carcass percentage, gut integrity, and metabolites profile. Most of the parameters outcome show linear patterns, indicating doses of EOs given are effective to facilitate better growth performance of broiler chickens. This study also demonstrated that in comparison to antibiotics, type of EOs have variable results for BWG, final BW, and FCR. Among EOs bioactive compounds, EO-Blend of thymol, carvacrol, and cinnamaldehyde showed higher efficacy in increasing productive performance and feed efficiency. These points confirm that EOs are suitable to be used as growth promoters and their economical benefit may be promising.

\section{CONFLICT OF INTEREST}

We certify that there is no conflict of interest with any financial organization regarding the material discussed in the manuscript.

\section{ACKNOWLEDGMENTS}

This study was financially supported by Institute of Research and Community Service of Universitas Sebelas Maret (LPPM UNS) through "Publishing Support in Top-Tier Journal" grant scheme of 2021 fiscal year.

\section{REFERENCES}

1. Franz C, Baser KHC, Windisch W. Essential oils and aromatic plants in animal feeding - a European perspective. a review. Flavour Fragr J 2010;25:327-40. https://doi.org/10.1002/ffj. 1967

2. Russo M, Galletti GC, Bocchini P, Carnacini A. Essential oil chemical composition of wild populations of italian oregano spice (Origanum vulgare ssp. hirtum (Link) Ietswaart): a preliminary evaluation of their use in chemotaxonomy by cluster analysis. 1. Inflorescences. J Agric Food Chem 1998; 46:3741-6. https://doi.org/10.1021/jf980087w

3. Brenes A, Roura E. Essential oils in poultry nutrition: Main effects and modes of action. Anim Feed Sci Technol 2010; 158:1-14. https://doi.org/10.1016/j.anifeedsci.2010.03.007

4. Stevanović ZD, Bošnjak-Neumüller J, Pajić-Lijaković I, Raj J, Vasiljević M. Essential oils as feed additives-Future perspectives. Molecules 2018;23:1717. https://doi.org/10.3390/mole cules 23071717

5. Khattak F, Ronchi A, Castelli P, Sparks N. Effects of natural blend of essential oil on growth performance, blood biochemistry, cecal morphology, and carcass quality of broiler chickens. Poult Sci 2014;93:132-7. https://doi.org/10.3382/ ps.2013-03387

6. Kim SJ, Lee KW, Kang CW, An BK. Growth performance, relative meat and organ weights, cecal microflora, and blood characteristics in broiler chickens fed diets containing different nutrient density with or without essential oils. AsianAustralas J Anim Sci 2016;29:549-54. https://doi.org/10.5713/ ajas. 15.0426

7. Pirgozliev V, Mansbridge SC, Rose SP, et al. Dietary essential oils improve feed efficiency and hepatic antioxidant content of broiler chickens. Animal 2019;13:502-8. https://doi.org/ 10.1017/S1751731118001520

8. Zeng Z, Zhang S, Wang H, Piao X. Essential oil and aromatic plants as feed additives in non-ruminant nutrition: a review. J Anim Sci Biotechnol 2015;6:7. https://doi.org/10.1186/ s40104-015-0004-5

9. Amad AA, Männer K, Wendler KR, Neumann K, Zentek J. Effects of a phytogenic feed additive on growth performance and ileal nutrient digestibility in broiler chickens. Poult Sci 2011;90:2811-6. https://doi.org/10.3382/ps.2011-01515

10. Basmacioğlu-Malayoğlu H, Ozdemir P, Bağriyanik HA. Influence of an organic acid blend and essential oil blend, individually or in combination, on growth performance, 
carcass parameters, apparent digestibility, intestinal microflora and intestinal morphology of broilers. Br Poult Sci 2016;57: 227-34. https://doi.org/10.1080/00071668.2016.1141171

11. Attia Y, Al-Harthi M, El-Kelawy M. Utilisation of essential oils as a natural growth promoter for broiler chickens. Ital J Anim Sci 2019;18:1005-12. https://doi.org/10.1080/182805 1X.2019.1607574

12. Aristimunha PC, Rosa AP, Boemo LS, et al. A blend of benzoic acid and essential oil compounds as an alternative to antibiotic growth promoters in broiler diets. J Appl Poult Res 2016;25: 455-63. https://doi.org/10.3382/japr/pfw015

13. Akbarian A, Golian A, Kermanshahi H, De Smet S, Michiels J. Antioxidant enzyme activities, plasma hormone levels and serum metabolites of finishing broiler chickens reared under high ambient temperature and fed lemon and orange peel extracts and Curcuma xanthorrhiza essential oil. J Anim Physiol Anim Nutr (Berl). 2015;99:150-62. https://doi.org/10. 1111/jpn. 12188

14. Wan XL, Song ZH, Niu Y, et al. Evaluation of enzymatically treated Artemisia annua L. on growth performance, meat quality, and oxidative stability of breast and thigh muscles in broilers. Poult Sci 2017;96:844-50. https://doi.org/10.3382/ ps/pew307

15. Khosravinia H. Mortality, production performance, water intake and organ weight of the heat stressed broiler chicken given savory (Satureja khuzistanica) essential oils through drinking water. J Appl Anim Res 2016;44:273-80. https:// doi.org/10.1080/09712119.2015.1031781

16. Aviagen. Nutrition specifications manual: Ross 308. Scotland, UK: Aviagen Ltd.; 2014.

17. Windisch W, Schedle K, Plitzner C, Kroismayr A. Use of phytogenic products as feed additives for swine and poultry. J Anim Sci 2008;86:E140-8. https://doi.org/10.2527/jas.20070459

18. St-Pierre NR. Invited review: Integrating quantitative findings from multiple studies using mixed model methodology. J Dairy Sci 2001;84:741-55. https://doi.org/10.3168/jds.S00220302(01)74530-4

19. Sauvant D, Schmidely P, Daudin JJ, St-Pierre NR. Metaanalyses of experimental data in animal nutrition. Animal 2008;2:1203-14. https://doi.org/10.1017/S175173110800 2280

20.Liberati A, Altman DG, Tetzlaff J, et al. The PRISMA statement for reporting systematic reviews and meta-analyses of studies that evaluate healthcare interventions: explanation and elaboration. BMJ 2009;339:b2700. https://doi.org/10. 1136/bmj.b2700

21.National Research Council. Nutrient requirements of poultry. 9th rev. ed. Washington, DC, USA: National Academies Press; 1994.

22. Jayanegara A, Wina E, Takahashi J. Meta-analysis on methane mitigating properties of saponin-rich sources in the rumen: influence of addition levels and plant sources. Asian-Australas J Anim Sci 2014;27:1426-35. https://doi.org/10.5713/ajas. 2014.14086

23. Hidayat C, Sumiati, Jayanegara A, Wina E. Effect of zinc on the immune response and production performance of broilers: a meta-analysis. Asian-Australas J Anim Sci 2020;33:465-79. https://doi.org/10.5713/ajas.19.0146

24. Noirot V, Moncoulon R, Sauvant D, Bayourthe C. Effect of essential oils and essential oils compounds supplementations in ruminant species: statistical analysis. Revue Méd Vét 2007; 158:589-97.

25.Abdel-Wareth AAA, Kehraus S, Südekum KH. Peppermint and its respective active component in diets of broiler chickens: growth performance, viability, economics, meat physicochemical properties, and carcass characteristics. Poult Sci 2019;98:3850-9. https://doi.org/10.3382/ps/pez099

26. Nameghi AH, Edalatian O, Bakhshalinejad R. Effects of a blend of thyme, peppermint and eucalyptus essential oils on growth performance, serum lipid and hepatic enzyme indices, immune response and ileal morphology and microflora in broilers. J Anim Physiol Anim Nutr 2019;103:1388-98. https:// doi.org/10.1111/jpn.13122

27. Hashemipour H, Kermanshahi H, Golian A, Veldkamp T. Effect of thymol and carvacrol feed supplementation on performance, antioxidant enzyme activities, fatty acid composition, digestive enzyme activities, and immune response in broiler chickens. Poult Sci 2013;92:2059-69. https://doi. org/10.3382/ps.2012-02685

28. Altop A, Erener G, Duru ME, Isik K. Effects of essential oils from Liquidambar orientalis Mill. leaves on growth performance, carcass and some organ traits, some blood metabolites and intestinal microbiota in broilers. Br Poult Sci 2018;59: 121-7. https://doi.org/10.1080/00071668.2017.1400657

29. Cross DE, Svoboda K, McDevitt RM, Acamovic T. The performance of chickens fed diets with and without thyme oil and enzymes. Br Poult Sci 2003;44(Suppl 1):18-9. https:// doi.org/10.1080/713655293

30. Malayoğlu HB, Baysal Ş, Misirliǒlu Z, Polat M, Yilmaz H, Turan N. Effects of oregano essential oil with or without feed enzymes on growth performance, digestive enzyme, nutrient digestibility, lipid metabolism and immune response of broilers fed on wheat-soybean meal diets. Br Poult Sci 2010;51:67-80. https://doi.org/10.1080/00071660903573702

31. Noy Y, Sklan D. Digestion and absorption in the young chick. Poult Sci 1995;74:366-73. https://doi.org/10.3382/ps.0740366

32.Jang IS, Ko YH, Kang SY, Lee CY. Effect of a commercial essential oil on growth performance, digestive enzyme activity and intestinal microflora population in broiler chickens. Anim Feed Sci Technol 2007;134:304-15. https://doi.org/10.1016/ j.anifeedsci.2006.06.009

33. Masouri L, Salari S, Sari M, Tabatabaei S, Masouri B. Effect of feed supplementation with Satureja khuzistanica essential 
oil on performance and physiological parameters of broilers fed on wheat- or maize-based diets. Br Poult Sci 2017;58:42534. https://doi.org/10.1080/00071668.2017.1327701

34.Lee KW, Everts H, Kappert HJ, Frehner M, Losa R, Beynen AC. Effects of dietary essential oil components on growth performance, digestive enzymes and lipid metabolism in female broiler chickens. Br Poult Sci 2003;44:450-7. https:// doi.org/10.1080/0007166031000085508

35. Ghazaghi M, Mehri M, Bagherzadeh-Kasmani F. Effects of dietary Mentha spicata on performance, blood metabolites, meat quality and microbial ecosystem of small intestine in growing Japanese quail. Anim Feed Sci Technol 2014;194: 89-98. https://doi.org/10.1016/j.anifeedsci.2014.04.014

36. Chao SC, Young DG, Oberg CJ. Screening for inhibitory activity of essential oils on selected bacteria, fungi and viruses. J Essent Oil Res 2000;12:639-49. https://doi.org/10.1080/ 10412905.2000.9712177

37.Lambert RJW, Skandamis PN, Coote PJ, Nychas GJE. A study of the minimum inhibitory concentration and mode of action of oregano essential oil, thymol and carvacrol. J Appl Microbiol 2001;91:453-62. https://doi.org/10.1046/j. 1365-2672.2001.01428.x

38. Park JH, Kim IH. Effects of a protease and essential oils on growth performance, blood cell profiles, nutrient retention, ileal microbiota, excreta gas emission, and breast meat quality in broiler chicks. Poult Sci 2018;97:2854-60. https://doi.org/ $10.3382 / \mathrm{ps} / \mathrm{pey} 151$

39. Xu J, Zhou F, Ji BP, Pei RS, Xu N. The antibacterial mechanism of carvacrol and thymol against Escherichia coli. Lett Appl Microbiol 2008;47:174-9. https://doi.org/10.1111/j.1472765X.2008.02407.x

40. Chen Y, Wang J, Yu L, Xu T, Zhu N. Microbiota and metabolome responses in the cecum and serum of broiler chickens fed with plant essential oils or virginiamycin. Sci Rep 2020; 10:5382. https://doi.org/10.1038/s41598-020-60135-x

41.Jamroz D, Wertelecki T, Houszka M, Kamel C. Influence of diet type on the inclusion of plant origin active substances on morphological and histochemical characteristics of the stomach and jejunum walls in chicken. J Anim Physiol Anim Nutr (Berl). 2006;90:255-68. https://doi.org/10.1111/j.14390396.2005.00603.x

42. Hamedi S, Shomali T, Ghaderi H. Effect of dietary inclusion of Mentha piperita L. on histological and histomorphometrical parameters of the small intestine in broiler chickens. Org Agric 2017;7:105-10. https://doi.org/10.1007/s13165-0160153-7

43.Xu ZR, Hu CH, Xia MS, Zhan XA, Wang MQ. Effects of dietary fructooligosaccharide on digestive enzyme activities, intestinal microflora and morphology of male broilers. Poult Sci 2003;82:1030-6. https://doi.org/10.1093/ps/82.6.1030

44.Zhang GF, Yang ZB, Wang Y, Yang WR, Jiang SZ, Gai GS. Effects of ginger root (Zingiber officinale) processed to different particle sizes on growth performance, antioxidant status, and serum metabolites of broiler chickens. Poult Sci 2009;88:2159-66. https://doi.org/10.3382/ps.2009-00165

45. Case GL, He L, Mo H, Elson CE. Induction of geranyl pyrophosphate pyrophosphatase activity by cholesterol-suppressive isoprenoids. Lipids 1995;30:357-9. https://doi.org/10.1007/ BF02536045

46.Supuka P, Marcinčàk S, Popelka $\mathrm{P}$, et al. The effects of adding agrimony and sage extracts to water on blood biochemistry and meat quality of broiler chickens. Acta Vet Brno 2015; 84:119-24. https://doi.org/10.2754/avb201584020119

47. Ghazalah AA, Ali AM. Rosemary leaves as a dietary supplement for growth in broiler chickens. Int J Poult Sci 2008; 7:234-9. https://doi.org/10.3923/ijps.2008.234.239

48. Amad AA, Wendler KR, Zentek J. Effects of a phytogenic feed additive on growth performance, selected blood criteria and jejunal morphology in broiler chickens. Emir J Food Agric 2013;25:549-54. https://doi.org/10.9755/ejfa.v25i7.12364

49. Hassan FAM, Awad A. Impact of thyme powder (Thymus vulgaris L.) supplementation on gene expression profiles of cytokines and economic efficiency of broiler diets. Environ Sci Pollut Res Int 2017;24:15816-26. https://doi.org/10.1007/ s11356-017-9251-7

50. Rahimi S, Teymouri Zadeh Z, Karimi Torshizi MA, Omidbaigi $\mathrm{R}$, Rokni H. Effect of the three herbal extracts on growth performance, immune system, blood factors and intestinal selected bacterial population in broiler chickens. J Agric Sci Technol 2011;13:527-39.

51.Tiihonen K, Kettunen H, Bento MHL, et al. The effect of feeding essential oils on broiler performance and gut microbiota. Br Poult Sci 2010;51:381-92. https://doi.org/10.1080/ 00071668.2010.496446

52. Reis JH, Gebert RR, Barreta M, et al. Effects of phytogenic feed additive based on thymol, carvacrol and cinnamic aldehyde on body weight, blood parameters and environmental bacteria in broilers chickens. Microb Pathog 2018;125:16876. https://doi.org/10.1016/j.micpath.2018.09.015

53. Galli GM, Gerbet RR, Griss LG, et al. Combination of herbal components (curcumin, carvacrol, thymol, cinnamaldehyde) in broiler chicken feed: Impacts on response parameters, performance, fatty acid profiles, meat quality and control of coccidia and bacteria. Microb Pathog 2020;139: 103916. https://doi.org/10.1016/j.micpath.2019.103916

54.Liu Y, Yang X, Xin H, et al. Effects of a protected inclusion of organic acids and essential oils as antibiotic growth promoter alternative on growth performance, intestinal morphology and gut microflora in broilers. Anim Sci J 2017;88:1414-24. https://doi.org/10.1111/asj.12782

55. Yang X, Liu Y, Yan F, Yang C, Yang X. Effects of encapsulated organic acids and essential oils on intestinal barrier, microbial count, and bacterial metabolites in broiler chickens. Poult Sci 2019;98:2858-65. https://doi.org/10.3382/ps/pez031 
56.Loh TC, Ling HG, Thanh NT, Foo HL, Rajion MA, David SI. Effects of feeding phytogenic substances and phytase on growth performance and nutrient digestibility of young broilers. J Appl Anim Res 2008;33:187-92. https://doi.org/10. 1080/09712119.2008.9706924

57.Ciftci M, Dalkilic B, Cerci IH, Guler T, Ertas ON, Arslan O. Influence of dietary cinnamon oil supplementation on performance and carcass characteristics in broilers. J Appl Anim Res 2009;36:125-8. https://doi.org/10.1080/09712119.2009. 9707045

58. Isabel B, Santos Y. Effects of dietary organic acids and essential oils on growth performance and carcass characteristics of broiler chickens. J Appl Poult Res 2009;18:472-6. https://doi. org/10.3382/japr.2008-00096

59. Amerah AM, Péron A, Zaefarian F, Ravindran V. Influence of whole wheat inclusion and a blend of essential oils on the performance, nutrient utilisation, digestive tract development and ileal microbiota profile of broiler chickens. Br Poult Sci 2011;52:124-32. https://doi.org/10.1080/00071668.2010.548 791

60. Alp M, Midilli M, Kocabağlı N, et al. The effects of dietary oregano essential oil on live performance, carcass yield, serum immunoglobulin G level, and oocyst count in broilers. J Appl Anim Res 2012;21:630-6. https://doi.org/10.3382/japr.201200551

61. Bravo D, Utterback P, Parsons CM. Evaluation of a mixture of carvacrol, cinnamaldehyde, and capsicum oleoresin for improving growth performance and metabolizable energy in broiler chicks fed corn and soybean meal. J Appl Poult Res 2011;20:115-20. https://doi.org/10.3382/japr.2010-00163

62. Bozkurt M, Küçükyilmaz K, Çatli AU, et al. Influences of an essential oil mixture supplementation to corn versus wheatbased practical diets on growth, organ size, intestinal morphology and immune response of male and female broilers. Ital J Anim Sci 2012;11:e54. https://doi.org/10.4081/ijas.2012. e54

63. Engberg RM, Grevsen K, Ivarsen E, et al. The effect of Artemisia апnиa on broiler performance, on intestinal microbiota and on the course of a Clostridium perfringens infection applying a necrotic enteritis disease model. Avian Pathol 2012;41:36976. https://doi.org/10.1080/03079457.2012.696185

64. Mueller K, Blum NM, Kluge H, Mueller AS. Influence of broccoli extract and various essential oils on performance and expression of xenobiotic- and antioxidant enzymes in broiler chickens. Br J Nutr 2012;108:588-602. https://doi. org/10.1017/S0007114511005873

65. Sarica S, Corduk M. Effects of oregano essential oil supplementation to diets for broiler chicks with delayed feeding after hatching. 1. Performances and digestibility of nutrients. Eur Poult Sci 2013;77:81-9.

66. Betancourt L, Rodriguez F, Phandanouvong V, et al. Effect of Origanum chemotypes on broiler intestinal bacteria. Poult
Sci 2014;93:2526-35. https://doi.org/10.3382/ps.2014-03944

67. Habibi R, Sadeghi GH, Karimi A. Effect of different concentrations of ginger root powder and its essential oil on growth performance, serum metabolites and antioxidant status in broiler chicks under heat stress. Br Poult Sci 2014;55:22837. https://doi.org/10.1080/00071668.2014.887830

68. Humer E, Rohrer E, Windisch W, et al. Gender-specific effects of a phytogenic feed additive on performance, intestinal physiology and morphology in broiler chickens. J Anim Physiol Anim Nutr 2015;99:788-800. https://doi.org/10.1111/ jpn. 12238

69. Ghazi S, Amjadian T, Norouzi S. Single and combined effects of vitamin $\mathrm{C}$ and oregano essential oil in diet, on growth performance, and blood parameters of broiler chicks reared under heat stress condition. Int J Biometeorol 2015;59:101924. https://doi.org/10.1007/s00484-014-0915-4

70.Pirgozliev V, Bravo D, Mirza MW, Rose SP. Growth performance and endogenous losses of broilers fed wheat-based diets with and without essential oils and xylanase supplementation. Poult Sci 2015;94:1227-32. https://doi.org/10.3382/ ps/peu017

71. Hafeez A, Männer K, Schieder C, Zentek J. Effect of supplementation of phytogenic feed additives (powdered vs. encapsulated) on performance and nutrient digestibility in broiler chickens. Poult Sci 2016;95:622-9. https://doi.org/10.3382/ ps/pev368

72.Ding X, Yang CW, Yang ZB. Effects of star anise (Illicium verum Hook.f.), essential oil, and leavings on growth performance, serum, and liver antioxidant status of broiler chickens. J Appl Poult Res 2017;26:459-66. https://doi.org/10.3382/ japr/pfx014

73. Mohiti-Asli M, Ghanaatparast-Rashti M. Comparison of the effect of two phytogenic compounds on growth performance and immune response of broilers. J Appl Anim Res 2017;45: 603-8. https://doi.org/10.1080/09712119.2016.1243119

74. Paraskeuas V, Fegeros K, Palamidi I, Hunger C, Mountzouris KC. Growth performance, nutrient digestibility, antioxidant capacity, blood biochemical biomarkers and cytokines expression in broiler chickens fed different phytogenic levels. Anim Nutr 2017;3:114-20. https://doi.org/10.1016/j.aninu. 2017.01.005

75. Ri CS, Jiang XR, Kim MH, et al. Effects of dietary oregano powder supplementation on the growth performance, antioxidant status and meat quality of broiler chicks. Ital J Anim Sci 2017;16:246-52. https://doi.org/10.1080/1828051X.2016. 1274243

76. Giannenas I, Bonos E, Skoufos I, et al. Effect of herbal feed additives on performance parameters, intestinal microbiota, intestinal morphology and meat lipid oxidation of broiler chickens. Br J Nutr 2018;59:545-53. https://doi.org/10.1080/ 00071668.2018.1483577

77. Hosseini SA, Meimandipour A. Feeding broilers with thyme 
essential oil loaded in chitosan nanoparticles: an efficient strategy for successful delivery. Br Poult Sci 2018;59:669-78. https://doi.org/10.1080/00071668.2018.1521511

78. Mohiti-Asli M, Ghanaatparast-Rashti M. Comparing the effects of a combined phytogenic feed additive with an individual essential oil of oregano on intestinal morphology and microflora in broilers. J Appl Anim Res 2018;46:184-9. https://doi.org/10.1080/09712119.2017.1284074
79. Nouri A. Chitosan nano-encapsulation improves the effects of mint, thyme, and cinnamon essential oils in broiler chickens. Br Poult Sci 2019;60:530-8. https://doi.org/10.1080/000716 68.2019.1622078

80. Placha I, Ocelova V, Chizzola R, et al. Effect of thymol on the broiler chicken antioxidative defence system after sustained dietary thyme oil application. Br Poult Sci 2019;60:589-96. https://doi.org/10.1080/00071668.2019.1631445 